Teologia i Moralność, Volumen 15(2020), numer 2(28)

doi: 10.14746/tim.2020.28.2.03

ORCID: 0000-0002-2367-0416

\author{
MAŁGORZATA GRUCHOŁA \\ Katolicki Uniwersytet Lubelski Jana Pawła II \\ Wydział Nauk Społecznych
}

\title{
Osoby starsze w świecie nowych mediów i technologii
}

\section{Wprowadzenie}

Na początku 2018 roku osoby starsze, a dokładniej ludność w wieku poprodukcyjnym, czyli kobiety po 60 . oraz mężczyźni po 65. roku życia, stanowiły 21\% (Główny Urząd Statystyczny 2019, 209) ogólnej liczby ludności Polski (38434 tys. - Główny Urząd Statystyczny 2019, 206). Liczbę tę należy powiększyć o osoby nieco młodsze (osoby 55+). Z danych Głównego Urzędu Statystycznego wynika, że liczba ta systematycznie wzrasta (6455,6 w 2010 r., 7769,5 w 2016 r., 7995,3 w 2017 r. - Główny Urząd Statystyczny 2019, 209; 8365,6 w 2019 r. - Główny Urząd Statystyczny 2020, 168). Także prognoza ludności w wieku poprodukcyjnym w Polsce przewiduje tendencje wzrostowe (8617000 w 2020 r., 9349000 w 2025 r. oraz 9750000 w 2030 r. - Główny Urząd Statystyczny 2019, 227). Analogiczne dane udostępniła Organizacja Narodów Zjednoczonych (ONZ). Z prognoz jej ekspertów wynika, że na świecie wzrasta odsetek osób po 65. roku życia i niedługo przewyższy on liczbę dzieci przed piątym rokiem życia. Wzrośnie on z 17,1\% w 2008 roku do 30\% w 2060 roku (z 84,6 do 151,5 mln, w tym liczba osób powyżej 80. roku życia wzrośnie trzykrotnie: z 21,8 do 61,4 mln; Szarota 2013, 7). Wobec diagnozowanej sytuacji demograficznej należy tworzyć rozwiązania prawne mogące poprawić jakość ich życia. Osoby starsze stanowią znaczną grupę społeczną i pokoleniową, która wymaga zaplanowanej polityki społecznej i kulturowej. Każda generacja funkcjonuje bowiem nie tylko w określonym systemie polityczno-gospodarczym, ale także kulturowym, w którym bezdyskusyjnie coraz większą rolę odgrywają media i technologie informacyjno-komunikacyjne. Warto zatem zastanowić się nad wzajemną relacją osób starszych i nowych mediów oraz technologii. 
Celem artykułu jest analiza porównawcza sytuacji i uwarunkowań społeczno-kulturowych oraz medialnych osób starszych tworzących przede wszystkim pokolenie X w świecie nowych mediów i technologii na tle najmłodszego pokolenia medialnego, czyli pokolenia Alpha. Przyjęłam tezę, że zgodnie z hipotezą opóźnienia kulturowego sformułowaną przez Williama Ogburna (Ogburn 1975, 255-258) świat rzeczywisty (społeczno-kulturowy i ekonomiczny), w którym funkcjonują osoby starsze, nie nadąża w wymiarze technologicznym za światem wytworzonym przez nowe media i technologie informacyjne oraz komunikacyjne (światem wirtualnym, postbiologicznym i posthumanistycznym). W celu rozwiązania tytułowego problemu zastosowałam metodę historyczną, analityczno-opisową, syntetyczną oraz porównawczą.

\section{Pokolenie osób starszych w kontekście pokoleń medialnych}

W literaturze przedmiotu socjologowie, pedagodzy czy psychologowie, podejmując się charakterystyki stylu życia, nawiązują do terminu ,pokolenia”, który najczęściej łączą z różnymi mediami jako kategoriami definiującymi doświadczenia typowe dla większości osób konkretnej generacji. Nazwy pokoleń medialnych zaproponował Jean-Pierre La France. Mając na uwadze hierarchię ważności mediów dla ich odbiorców, wyróżnił on pokolenie:

1) telewizyjne (lata 60. XX w.), pokolenie wideo (lata 70. XX w.) oraz pokolenie Nintendo (lata 80 . XX w.), opisywane w literaturze przedmiotu jako pokolenie X;

2) komputera $\mathrm{i}$ technologii internetowych (lata 90. XX w.) określane jako pokolenie $\mathrm{Y}$

3) smartfonów, iPodów oraz mediów społecznościowych (pierwsza dekada XXI wieku): pokolenie Z;

4) Internetu Rzeczy, Internetu Semantycznego, elektronicznych gadżetów (druga dekada XXI wieku i kolejne): pokolenie Alpha.

Osoby starsze stanowią więc pokolenie medialne X. Pomijając szczegółową analizę kolejnych pokoleń medialnych, która jest przedmiotem innych publikacji (Gruchoła 2014, 31-48; 2016, 5-13; 2017, 123-133), podam syntetyczną charakterystykę najstarszego pokolenia medialnego: $\mathrm{X}$ oraz najmłodszego: Alpha, by wykazać różnice i dokonujące się zmiany. Przywołam także wcześniejsze pokolenia: pokolenie wojny czy międzywojnia oraz Baby Boomers (Baby Boomers 2019). Chociaż według literatury przedmiotu nie są one pokoleniami medialnym, jednak ich charakterystyka pozwoli lepiej zrozumieć tożsamość i mentalność osób starszych (Grzesiak 2019). Obecne poko- 
lenie seniorów tworzą: pokolenie wojny, międzywojnia, Baby Boomers oraz pokolenie X.

Najstarszych seniorów (osoby po 70. roku życia), którzy urodzili się w czasie II wojny światowej i wcześniej, nazywamy pokoleniem wojny czy międzywojnia. W czasach młodości korzystali z mediów drukowanych (prasy, książek) oraz z technologii radiowych. Generacja ta w minimalnym stopniu jest użytkownikiem nowych mediów. Kolejne pokolenie, określane jako Baby Boomers (BB), to osoby urodzone po zakończeniu II wojny światowej (1946-1964). Musiały myśleć przede wszystkim o pracy zawodowej i utrzymaniu rodziny w odbudowującym się państwie. Są słabo obeznane z nowymi technologiami, których nieustannie muszą się uczyć. Preferują tradycyjne media: prasę, książkę, radio, wideo i telewizję. Rzadko korzystają z Internetu, aplikacji mobilnych oraz social mediów. Z uwagi na brak kompetencji medialnych nie są świadomi zagrożeń w cyberprzestrzeni (Sadowski 2019).

Pokolenie X, opisane przez Duglasa Couplanda (Coupland 2008), określane także jako Latchkey Kind, tworzą osoby urodzone w latach 1961-1981 (Isaksen 2019). Ich pierwszą rzeczywistość medialną wyznaczają prasa, książka, radio, telewizor i wideo, czyli media jednokierunkowe, tzw. gorące, charakteryzujące się oddziaływaniem na jeden zmysł, zapewniające „ostrą percepcję", nie aktywizujące odbiorcy. W wieku dojrzałym osób z pokolenia X pojawiły się pierwsze komputery oraz gry wideo. Wychowani w dobie telewizji preferują ją w stosunku do komputerów i rozwiązań mobilnych. Obsługa nowych technologii nie stanowi dla nich większego problemu. Odnajdują się w komunikacji i rozwiązaniach e-mailowych. Jednak nie są tak często online w mediach społecznościowych jak młodsze pokolenia. Nie lubią zmieniać rozwiązań, które znają z okresu młodości (Sadowski 2019, 1).

Dzieci urodzone po 2010 roku stanowią pokolenie Alpha (Google Kids; Top definition 2019) prognozowane i opisane przez Petera McDonalda, Marka McCrindle'a i Emily Wolfinger (McCrindle i Wolfinger 2009), Sherry Turkle (Turkle 2013). Rzeczywistość tego pokolenia, coraz bardziej wirtualną, wyznaczają: iPod, iPad, iPhone, gadżety elektroniczne, ubieralna technologia, Internet Web 3.0 (m.in. semantyczny: wzbogacenie treści o kontekst), Web 4.0 (Internet Rzeczy - Kokot i Kolenda 2015, 81, Internet Wszechrzeczy), sztuczna inteligencja, boty komunikacyjne. Nie wyobrażają sobie życia bez Internetu, social mediów, smartfona, tabletu i nowoczesnych technologii. Dominacja mediów zimnych przekazujących odbiorcy mało informacji, które domagają się dopełnienia, wymusza aktywność odbiorcy; musi on być nieustannie ak-

\footnotetext{
${ }^{1}$ Internet Rzeczy, Internet Wszystkich Rzeczy: „ekosystem, w którym urządzenia elektroniczne są połączone poprzez sieć internetową i komunikują się między sobą, za pośrednictwem człowieka lub bez jego udziału".
} 
tywny. Ponadto zmienił się model komunikacji oraz rola nadawcy i odbiorcy. Jednokierunkowe przesyłanie informacji typowe dla tradycyjnych mediów oraz Internetu pierwszej generacji (pokolenie X i wcześniejsze) obecnie współistnieje $\mathrm{z}$ dwukierunkową wymianą danych, możliwością samodzielnej publikacji treści. Internauta jest aktywnym komentatorem, ekspertem, krytykiem oraz autorem; nie jest tylko biernym odbiorcą treści, co było postawą typową dla pokolenia $\mathrm{X}$ (Web. 1.0).

Należy także nadmienić zmiany w obszarze percepcji mediów. Generacja $\mathrm{X}$ jest pierwszym pokoleniem dorastającym w rzeczywistości zmediatyzowanej. Treści upowszechniane w mediach stają się przede wszystkim ważnym komponentem tworzenia tożsamość odbiorcy, są ramą odniesienia dla interpretacji rzeczywistości społecznej. Funkcję informacyjną i rozrywkową należy uznać za wtórną wobec funkcji tożsamościowej. Natomiast pokolenie Alpha jest - przede wszystkim - pierwszym pokoleniem ,zanurzonym” w nowych technologiach internetowych (Internet Semantyczny, Internet Rzeczy, Internet Wszechrzeczy). Już doświadcza ono nowego systemu edukacji czy rozrywki opartego na narzędziach i aplikacjach do zdalnego nauczania. Nowe media, technologie internetowe stanowią naturalne środowisko niezbędne do sprawnego, codziennego funkcjonowania. Można przypuszczać, że analogicznie jak nieco młodsze pokolenie $Z$, nowe media i technologie będzie postrzegać jako możliwość poszerzenia swojego życia i osobowości, fizycznej i psychicznej bytności poprzez sztucznie wykreowane tożsamości, w odróżnieniu do $\mathrm{X}$, traktujących je jako narzędzie do pozyskiwania informacji i komunikowania się. Snuje wielkie plany życiowe i zawodowe w powiązaniu z nowoczesną technologią. Korzysta równocześnie z wielu rozwiązań i urządzeń. Wiedzę i umiejętności czerpie z aplikacji, blogów, forów i platform społecznościowych. Dzięki mobilnym technologiom szybko wyszukuje potrzebne informacje i znajduje odpowiedzi na nurtujące problemy. Dzieli się wiedzą, ale i pytaniami z innymi w świecie online (szczególnie poprzez media społecznościowe i komentarze, oceny produktów i usług). Najchętniej chłonie kontent w postaci obrazu i wideo, czyli komunikacji wizualnej. Jest ciągle online. Przedkłada smartfony i technologie mobilne ponad komputery. Nie ogląda telewizji, która narzuca pewne ramy czasowe (Sadowski 2019, 1). Ceni wolność i niezależność.

Zróżnicowana hierarchia ważności mediów i nowych mediów implikuje inny rodzaj relacji międzyludzkich. Generacja X i wcześniejsze wzrastały w czasach, kiedy normą były bezpośrednie społeczne interakcje człowieka z człowiekiem w świecie fizycznym. Stąd ich reprezentanci preferują kontakty osobiste face-to-face oraz symulujące taką rozmowę (np. telefoniczne). Dla pokolenia Alpha świat wirtualny i fizyczny przeplata się z elementami rzeczywistości rozszerzonej oraz sztucznej inteligencji. Generacja ta wybiera kontakty pośrednie e-mailowe i poprzez komunikatory oraz social media. Interakcje 
z człowiekiem zastępuje interakcja z chatbotem, sztuczną inteligencją, ubieralną technologią, cyborgiem oraz robotem społecznym (humanoidalnym). Sherry Turkle wprost napisała o „nowej bliskości w samotności”, podkreślając znaczenie „nowych podmiotów” społecznych. „Dorastające w otoczeniu smartfonów i robotów-zabawek, pozbawione poczucia bezpieczeństwa w relacjach, targane lękiem przed bliskością - w zdobyczach techniki szukać będzie sposobów na trwanie w iluzji związku, a równocześnie ochrony przed nim" (Turkle 2013, 70). Wspomina także o „samotni w bliskości”. Młodzi ludzie, chociaż mają wielu znajomych w mediach społecznościowych, tysiące polubień, czują się osamotnieni i opuszczeni. Podobnie jak w pokoleniu Z - co budzi niepokój i niezgodę starszego pokolenia - zanika rozróżnienie między sferą publiczną a sferą prywatną, intymną, bardzo osobistą. Częściej komunikują się przez ciągły ,,przepływ” informacji wizualnych w świecie wirtualnym (portale społecznościowe, platformy edukacyjne, gry sieciowe, galerie) niż przez pojedyncze informacje tekstowe (np. wiadomość SMS) czy bezpośrednie rozmowy „twarzą w twarz”. Komunikację werbalną, tekstową zastępują komunikacją wizualną, obrazkową. Mają ogromną potrzebę kontaktu $\mathrm{z}$ rówieśnikami, ale głównie w świecie wirtualnym. Ważne jest dla nich budowanie wirtualnych, anonimowych relacji społecznych. Do pisania używają iPodów, tabletów i laptopów. Są nieustannie podłączeni do Internetu, nawet podczas snu. Większość czynności jest realizowana za pomocą smartfona. Inne cechy pokolenia to: przejście od myślenia analitycznego do symulacji (wirtualna rzeczywistość, ,don’t think, process it”), dominacja komunikacji nad myśleniem, budowanie tożsamości ,wsobnej” przez przynależność do sieci wirtualnych w miejsce tożsamości realnie funkcjonujących grup społeczno-kulturowych (Muraszkiewicz 2019).

Ta krótka i lapidarna prezentacja pokoleń (X i Alpha) potwierdza, że są to już inne pokolenia, funkcjonujące $\mathrm{w}$ różnych rzeczywistościach, nie tylko medialnych. Osoby starsze, dla których początkowym i dominującym światem był ten fizyczny, realny, muszą dostosować się do nowej - w pełni mediatyzowanej, często wirtualnej i/lub rozszerzonej - rzeczywistości. Jednym z koniecznych warunków jest posiadanie kompetencji medialnych w zakresie wiedzy, umiejętności oraz postaw.

\section{Kompetencje medialne osób starszych}

Gdyby zapytać współczesnego Polaka o jego umiejętności cyfrowe, większość określiłaby je jako wysokie. Fakt, że codziennie ponad $70 \%$ z nich korzysta z Internetu, nie oznacza, że mają niezbędne kompetencje medialne. Stwierdzenie to odnosi się także do osób młodych. Jak wynika z badań Eu- 
robarometru przeprowadzonych przez Kantar Public na zlecenie Komisji Europejskiej w 2017 roku, blisko trzy czwarte Polaków (73\%) postrzega siebie samych jako mjących wystarczające kompetencje do używania cyfrowej technologii w codziennym życiu (Kantar Public 2017, 3)². Warto jednak zwrócić uwagę na inny wynik. Jedna czwarta Polaków (24\%) uważa, że nie ma takich umiejętności (Kantar Public 2017, 3). Najmniejsze umiejętności w korzystaniu z technologii cyfrowych deklarują osoby starsze (Kantar Public 2017, 3). W wieku 55 i więcej lat mniej niż połowa, bo 47\% badanych, deklaruje, że ma takie umiejętności. Kompetencji cyfrowych brakuje przede wszystkim pokoleniu wojny, międzywojnia, Baby Boomers i gorzej wykształconym osobom $\mathrm{z}$ pokolenia $\mathrm{X}$. W tej dziedzinie mogą one liczyć na pomoc pokolenia Y i Z (kultura prefiguratywna), w tych bowiem gospodarstwach, w których są dzieci i młodzież, poziom samooceny umiejętności związanych z technologiami cyfrowymi jest na wyższym poziomie $(80 \%)$ niż u pozostałych $(64 \%$; Kantar Public 2017, 3).

Mniej optymistyczne są wyniki z badań przeprowadzonych przez DESI 2017 (The Digital Economy and Society Index; Janiszewska 2019) ${ }^{3}$. Mniej niż połowa (bo 44\%) Polaków (UE - 56\%) ma podstawowe umiejętności cyfrowe ${ }^{4}$, choć $70 \%$ korzysta z Internetu (UE - 79\%). Dla polskiej młodzieży (w wieku 16-24 lata) wskaźnik wynosi 81\% (UE - 81\%), a dla osób w wieku 65-74 lata: tylko 8\% (UE - 24\%). Z powyższych danych wynika, że obecnie zdecydowana większość seniorów nie ma wystarczających bądź nie ma żadnych umiejętności cyfrowych (Janiszewska 2019, 1). Bezpośrednim skutkiem ich braku jest wykluczenie cyfrowe. Wyżej przywołane liczby wskazują, jak wiele osób dotkniętych jest tym zjawiskiem.

${ }^{2}$ Ogólnoeuropejskie badania Eurobarometr, przeprowadzone przez Kantar TNS na zlecenie Komisji Europejskiej w dniach 18-27 marca 2017 roku. Próba: ogólnopolska próba 1008 mieszkańców Polski w wieku 15 i więcej lat; reprezentatywna próba 27901 mieszkańców z 28 krajów członkowskich Unii Europejskiej w wieku 15 i więcej lat. Technika: wywiady bezpośrednie wspomagane komputerowo (CAPI).

${ }^{3}$ Indeks Gospodarki Cyfrowej i Społeczeństwa Cyfrowego (DESI - Digital Economy and Society Index) obejmuje pięć obszarów: (1) Łączność (stałe sieci szerokopasmowe, mobilne usługi szerokopasmowe, prędkość i ceny łączy szerokopasmowych). (2) Kapitał ludzki (podstawowe i zaawansowane umiejętności cyfrowe). (3) Wykorzystanie Internetu (korzystanie z treści internetowych, komunikacja i przeprowadzanie transakcji przez Internet). (4) Integracja technologii cyfrowej (cyfryzacja przedsiębiorstw i handel elektroniczny). (5) Cyfrowe usługi publiczne (e-administracja).

${ }^{4}$ Podstawowe umiejętności cyfrowe obejmują: obsługę poczty elektronicznej, komunikatora tekstowego, znajomość zabezpieczeń, wiedzę o istocie haseł i loginów, obsługę narzędzi biurowych, wykonywanie kopii zapasowych plików i umiejętność weryfikacji informacji znalezionych w sieci. 


\section{Zjawisko wykluczenia cyfrowego osób starszych}

Pod koniec lat 90. XX wieku do dyskursu naukowego o społecznych i kulturowych konsekwencjach funkcjonowania mediów został wprowadzony termin: wykluczenie cyfrowe (digital divide). Wśród wielu propozycji definicji (więcej: Gruchoła 2015, 113-128) dla porównania podam jego rozumienie zaproponowane przez Agnieszkę Szewczyk oraz Łukasza Arendta. W ujęciu A. Szewczyk wykluczenie cyfrowe zakłada: ,podział na tych, którzy mają dostęp do technologii informacyjnej oraz komunikacyjnej i potrafią z nich korzystać, i tych, którzy tego dostępu nie mają bądź nie potrafią z niego korzystać" (Szewczyk 2006, 151). Łukasz Arendt zauważa zaś, że wykluczenie cyfrowe to ,przepaść dzieląca tych, którzy znajdują się po właściwej stronie, «zasobnej» w technologie informacyjne, gdzie dostęp do nich zapewnia pełny udział w nowoczesnym społeczeństwie oraz tych, którzy są po stronie niewłaściwej, skazani na niebyt w cyfrowym świecie" (Arendt 2010, 22).

Jan van Dijk, poszukując przyczyn wykluczenia cyfrowego, skonstruował model, który obrazując podstawowe elementy analizowanego zjawiska, częściowo tłumaczy stosunek osób starszych do nowych mediów. Rozróżnił on cztery kolejne rodzaje dostępu do technologii internetowych: motywacyjny, materialny i fizyczny, kompetencyjny oraz użytkowy (van Dijk 2010, 250). Model ten należy rozpatrywać w następujących wymiarach: psychologicznym (dostęp motywacyjny: motywacja do korzystania), technologicznym (dostęp materialny: posiadanie narzędzia dostępu do Internetu) oraz społecznym (dostęp kompetencyjny: umiejętności strategiczne, informacyjne, operacyjne i dostęp użytkowy: różne zastosowania), stanowiących obszar wykluczenia cyfrowego.

\subsection{Wymiar psychologiczny (dostęp motywacyjny)}

Proces przyswajania nowych mediów i technologii rozpoczyna się od dostępu motywacyjnego. Motywacja wpływa na decyzje nie tylko o zakupie smartfona, laptopa lub usługi połączenia z globalną siecią, ale także chęci przyswojenia wiedzy i opanowania niezbędnych kompetencji medialnych (wiedzy, umiejętności, postaw) w posługiwaniu się oraz wykorzystaniu możliwości, jakie niosą ze sobą nowe technologie, pokonania uprzedzeń, stereotypów czy obaw i lęków. U osób starszych motywacja ta jest często niewystarczająca. Powody mogą być różne. Część z nich nie ma ochoty korzystać z nowych technologii, co może być warunkowane koniecznością uczenia się, nabycia nowych umiejętności, postaw i kompetencji medialnych, zjawiskiem dysonansu poznawczego czy filtru przekazu, psychologicznym oporem przed 
zmianami: „zjawisko oporu C. Hovlanda”, inni nie lubią lub wręcz się ich boją; cierpią na tzw. „technofobię”. Bezpośrednią przyczyną braku motywacji może być także niedobór zasobów intelektualnych, społecznych i kulturalnych (zob. van Dijk 2010, 251). Także zbyt wysoka cena iPoda, iPada, iPhone'a, nowych technologii (ubieralnej technologii, elementów Internetu Rzeczy czy robota społecznego) może zniechęcić niejednego seniora.

\subsection{Wymiar technologiczny (dostęp materialny i fizyczny)}

Po pokonaniu pewnych barier mentalnych, lęków, często uprzedzeń i stereotypów, problemem dla osoby starszej może stać się dostęp fizyczny i materialny. Jest on niezbędnym warunkiem kolejnych rodzajów dostępu: kompetencyjnego oraz użytkowego (zob. van Dijk 2010, 252). Bywa on ograniczany poprzez warunkowość dostępu (zakup technologii, opłata za usługę, konieczność zarejestrowania się, założenie profilu, konta). Natomiast czynnikami sprzyjającymi i umożliwiającymi dostęp fizyczny osobom starszym są zasoby czasowe (posiadanie niezbędnego czasu pozwalającego na korzystanie z nowych mediów i technologii) oraz społeczne (funkcjonowanie w społeczeństwie, które zachęca do uzyskania dostępu i w tym pomaga, chociażby członkowie rodziny, stowarzyszenia konsumenckie poprzez organizacje kursów i szkoleń). Urządzenia z zakresu telemedycyny i teleopieki tworzą zasoby zdrowotne/medyczne (mobilne urządzenia elektroniczne z zakresu technologii ubieralnej monitorujące stan zdrowia) oraz rehabilitacyjne (m.in. roboty relacyjne redukujące stres pacjentów, stosowane w szpitalach i domach opieki społecznej). Kolejną grupę wyznaczają zasoby użytkowe (m.in. Internet Rzeczy wykorzystywany w skali makro, mikro i sąsiedzkiej ułatwiający i usprawniający wykonywanie codziennych czynności życiowych).

Funkcjonowanie generacji e-seniorów, która nie ma problemu $\mathrm{z}$ tzw. „technostresem”, w odróżnieniu do pokolenia Alpha, wciąż nie jest powszechnym zjawiskiem. Należy zmienić ich stosunek nie tylko do iPodów, laptopów, smartfonów, ale także do technologii ubieralnych, Internetu Rzeczy, które wciąż budzą lęk, a przecież mogą ułatwić codzienne życie, włącznie z ochroną zdrowia i życia. Konieczna jest zmiana percepcji nowych mediów; odejście od funkcji tylko informacyjnej na rzecz funkcji użytkowej i konsumpcyjnej.

\section{- Technologie ubieralne (wearables technology)}

Wearables technology, podobnie jak telefony i smartfony, których rynki konsumenckie można podzielić na segmenty dla juniora i seniora, są przystosowywane do oczekiwań i zdolności danej grupy użytkowników. W przypadku technologii ubieralnych zdecydowanie najwięcej ofert adreso- 
wanych jest do seniorów. Urządzenia elektroniczne, inteligentna odzież, smartwatch i opaski itd. $z$ dostępem do sieci Internet, łatwe do użytkowania i noszenia, wygodne oraz praktyczne spełniają jednocześnie od kilku do kilkunastu funkcji. Przede wszystkim poprzez monitoring aktywności seniora czy zapewnienie opieki i bezpieczeństwa służą ochronie zdrowia, ułatwiając wykonywanie codziennych czynności. Są wsparciem dla osób samotnie mieszkających, wymagających odpowiedniej uwagi i opieki. Stanowiąc oś relacji technologia/ maszyna-człowiek, przetwarzają informacje $\mathrm{z}$ otoczenia i z ciała użytkownika w czasie rzeczywistym. Za pośrednictwem technologii Bluetooth gromadzą dane do aplikacji połączonej ze smartfonem czy tabletem. System niewielkich znaczników wraz z centralnym hubem, czyli niezależnych gadżetów do rozmieszczenia $\mathrm{w}$ domu (inteligentne bransoletki, opaski, zegarki), przypomina seniorom o np. konieczności wzięcia leków czy innych ważnych czynnościach (przyjęciu posiłków). Rozszerzona platforma zawiera naręczny ekran w formie zegarka, gdzie znajdują się przypomnienia i alerty (np. na temat leków, posiłków lub innych elementów, które sparowano ze znacznikami). System ten posiada także detekcję upadków, a wszystkie ostrzeżenia i odczyty z czujników przez e-mail, wiadomość tekstową lub mobilną aplikację są przesyłane do zainteresowanych, wcześniej wskazanych członków rodziny i opiekunów (Sitnik 2019). Inny przykład noszonych technologii to elektroniczny plaster sterowany iPodem, redukujący ból użytkownika; oprogramowanie zamieszczone w smartfonie, które tłumaczy język migowy poprzez zbieranie impulsów elektronicznych z ruchów ramion, palców i nadgarstków za pomocą elektrod rozmieszczonych na skórze osoby niesłyszącej; inteligentne (smart) soczewki umożliwiają osobom chorym na cukrzycę kontrolowanie poziomu glukozy we krwi - sensory wbudowane w szkła kontaktowe sygnalizują wprost do oka informację o przekroczeniu dozwolonego poziomu glukozy (Bochyńska 2019).

Współczesne technologie informacyjne i komunikacyjne zakładają noszenie wielu czujników i sensorów biometrycznych, zintegrowanych z bazami danych medycznych, które coraz częściej służą do diagnozowania chorób lub zmian w organizmie w czasie rzeczywistym (np. bransoletki i opaski fitness wykrywają choroby przez samo tylko noszenie i monitorowanie aktywności) (Sitnik 2019, 1). Stąd ,przenikanie się technologii, które dzięki nietypowemu połączeniu są w stanie jeszcze lepiej pomagać ludziom, to ważny krok w rozwoju usług medycznych i okołomedycznych" - zauważa Paweł Popek (Tomaszewski 2019). Urządzenia ubieralne sprawdzają się nie tylko w codziennym życiu, sporcie, rozrywce, a także - a może przede wszystkim - w telemedycynie. Dzięki możliwości podłączenia ich do sieci internetowej coraz więcej osób starszych może funkcjonować we własnych domach, zamiast w klinikach, szpitalach czy placówkach pomocy społecznej, stwarzając szansę na swobodne działanie, ale przede wszystkim lepsze samopoczucie, które 
odgrywa kluczową rolę w procesie powrotu do zdrowia. Interfejsem systemu często są bransoletki, opaski oraz zegarki, noszone przez osoby starsze, chore oraz z niepełnosprawnością. Znajdujący się na nich przycisk automatycznie łączy je z teleasystentem, który na monitorze widzi informacje medyczne, takie jak zażywane leki, przebyte choroby, stan psychiczny i motoryczny oraz dane teleadresowe osoby zgłaszającej pomoc. System teleopieki sporządza aktualizowaną na bieżąco bazę danych o jego podopiecznych. Zbiera informacje zarówno o jego użytkownikach (zgłoszenia, dane kontaktowe, przebyte choroby, stan psychiczny, informacje o stanie zdrowia, sytuacja życiowa, samodzielność), jak i pracownikach oraz wolontariuszach (zadania, kompetencje, uprawnienia, zobowiązania, informacje o dostępności), świadczonych usługach (harmonogram wraz z opisem wizyt środowiskowych, historia zgłoszeń) oraz zastosowanych urządzeniach i technologiach.

Jeżeli z seniorem/podopiecznym, który uruchomił sygnał alarmowy, nie ma kontaktu, wówczas teleasystenci mogą zaalarmować i wysłać na miejsce służby ratunkowe bądź rodzinę. Obok całodobowej opieki, analizowany system umożliwia efektywne planowanie, realizację i monitoring wielu usług społecznych - w tym wizyt pracowników służby zdrowia, pracowników socjalnych, asystentów rodziny oraz wolontariuszy (Tomaszewski 2019, 1).

Należy zauważyć, że obok licznych udogodnień technologie ubieralne mają też swoją negatywną stronę: zagrożenie dla danych osobowych i prywatności. Urządzenia gromadzą wiedzę o użytkowniku: jego imię i nazwisko, miejsca, w których przebywa, tryb życia, rytm pracy serca, stan zdrowia (cenne informacje dla branży ubezpieczeniowej), a przechowywane dane przetwarzane są w czasie rzeczywistym i kumulowane w chmurze, co w obliczu rosnącej liczby cyberzagrożeń i cyberprzestępstw staje się coraz bardziej dekonspirujące.

\section{- Urządzenia Internetu Rzeczy (Internet of Things: IoT)}

Internet Rzeczy, Internet Przedmiotów, Internet Urządzeń czy Internet Wszechrzeczy umożliwia komunikację nie tylko ludzi z inteligentnymi przedmiotami (smart objects), co charakteryzuje ubieralną technologię, lecz także komunikację wyłącznie pomiędzy takimi ,inteligentnymi” przedmiotami i urządzeniami. Zapewnia więc komunikację ,zawsze (anytime) i wszędzie, czyli w dowolnym miejscu (anywhere/anyplace), za pomocą każdego nośnika informacji (anymedia) i czegokolwiek, czyli wszystkiego (anything) (Atzori, Iera i Morabito 2010, 2803), nie tylko ludzi (anyone), najlepiej przy wykorzystaniu dowolnej sieci (any network) i wszystkich usług (any service)" (cyt. za: Kwiatkowska 2014, 60; Internet of Things 2019). Z punktu widzenia normalizacji technicznej może być postrzegany jako globalna infrastruktura dla mobilnego społeczeństwa informacyjnego, umożliwiająca świadczenie 
zaawansowanych usług poprzez połączenie fizycznych i wirtualnych rzeczy, przedmiotów, urządzeń, maszyn.

Podobnie jak ubieralna technologia może znacznie ułatwić codzienne funkcjonowanie osób starszych. Światło inteligentnej lampy naściennej wyposażone w wykrywacze ruchu, automatycznie zapala się, gdy zarejestruje zmianę położenia osób starszych, np. wstających w środku nocy, a jeśli upadną, urządzenie może wysyłać alarmy do ich opiekunów. Światło rozpoznaje również zmiany w ruchach użytkownika, jeśli więc starszy człowiek idzie do łazienki częściej niż zwykle, światło wykryje to i poinformuje rodzinę (Mejssner 2019). Inteligentny zamek łączący się ze smartfonami przez Bluetooth umożliwia seniorom otwieranie drzwi za pomocą telefonów, bez konieczności szukania kluczy w kieszeniach. Natomiast czujnik jakości powietrza w domu monitoruje poziom $\mathrm{CO}_{2}$, temperaturę i wilgotność. Gadżet łączy się bezprzewodowo z urządzeniem mobilnym za pośrednictwem aplikacji, aby udostępniać te informacje użytkownikom i odpowiednim służbom, a także może łączyć się z innymi urządzeniami, aby automatycznie poprawić jakość powietrza w przestrzeni domowej (Mejssner 2019, 1).

Chociaż coraz więcej domowych urządzeń wyposażonych w czujniki i sensory podłączonych do Internetu ułatwia codzienne życie: od inteligentnych zamków po inteligentne lampy czy monitory, to należy jednak pamiętać, i uwrażliwiać osoby starsze, by używając ich, przestrzegały zasad bezpieczeństwa korzystania z Internetu, ważnego elementu kompetencji medialnych.

\subsection{Wymiar społeczny (dostęp kompetencyjny i użytkowy)}

Wzbudzenie motywacji do korzystania z nowych mediów i technologii oraz uzyskanie do nich dostępu umożliwia dostęp kompetencyjny, czyli wykształcenie pewnych umiejętności. Oznaczają one zdolność do stosowania wiedzy oraz korzystania z know-how w celu rozwiązywania problemów i wykonywania zadań. W kontekście Europejskich Ram Kwalifikacji umiejętności określa się jako operacyjne, praktyczne, strategiczne (obejmujące sprawność manualną i korzystanie z metod, materiałów, narzędzi i instrumentów) oraz informacyjne, poznawcze/kognitywne (obejmujące myślenie logiczne, intuicyjne i kreatywne) (Zalecenie Rady 2019). Umiejętności operacyjne pozwalają obsługiwać oprogramowanie, aplikacje, media, technologie. Umiejętności informacyjne są potrzebne do wyszukiwania, selekcjonowania i przetwarzania uzyskanych informacji. Umiejętności strategiczne natomiast umożliwiają wykorzystywanie tych źródeł jako środków do realizacji określonych celów oraz do zmiany statusu społecznego (w gospodarstwie domowym, w relacjach społecznych i towarzyskich). Należy zauważyć, że nierówności w obszarze do- 
stępu kompetencyjnego osób starszych nie wynikają z nierównej dystrybucji zasobów materialnych, ale intelektualnych (umiejętności zdobywania i krytycznego przetwarzania informacji), pozycyjnych umiejętności strategicznych oraz zasobów kulturowych, społecznych i osobowościowych (zob. van Dijk 2010, 252-253).

Wymienione rodzaje dostępu (motywacyjny, materialny i kompetencyjny) są konieczne, ale niewystarczające do posługiwania się nowymi mediami i technologiami. Należy bowiem podkreślić, że osoby starsze mogą być zmotywowane do korzystania $\mathrm{z}$ technologii, mogą mieć do nich dostęp fizyczny oraz opanować niezbędne umiejętności medialne, a mimo to nie odczuwać potrzeby lub nie mieć obowiązku, czasu czy siły, aby faktycznie z nich korzystać. Dostęp użytkowy, bo o nim mowa, obok wymienionych powyżej kategorii pozycyjnych oraz osobowych, uwarunkowany jest osobnym zestawem czynników. Mogą to być określone umiejętności, poziom wykształcenia, wiek, płeć, kultura oraz czas i możliwości w nabywaniu nowych kompetencji medialnych umożliwiających użytkowanie technologii (zob. van Dijk 2010, 253-254). Może to być także opór natury psychologicznej, ale i etycznej wobec nowych technologii (ubieralne technologie, cyborgizacja: egzorozszerzenia i endorozszerzenia), narzędzi często ingerujących w naturę człowieka (technologie stosowane $\mathrm{w}$ transhumanizmie: mind uploading), ale $\mathrm{i}$,nowych podmiotów społecznych" (robotów humanoidalnych). Kolejnym czynnikiem może być niezgoda na problem uspołecznienia sztucznej inteligencji (robotów relacyjnych) poprzez jej aplikację w różne obszary funkcjonowania człowieka. Mogą to być obawy oraz brak umiejętności funkcjonowania w zalgorytmizowanej i stechnicyzowanej codziennej rzeczywistości: e-medycyna, e-porady, e-administracja, e-handel, e-usługi itd. Poruszana problematyka jest bardzo obszerna, stąd w niniejszej publikacji ograniczę się tylko do wybranych jej aspektów: nowych ,podmiotów społecznych”.

- Nowe ,podmioty społeczne”: roboty relacyjne

Postępujące sprawności komunikacyjne i społeczne w zakresie interakcji maszyna - człowiek sprawiły, że coraz częściej są one postrzegane nie tylko jako użyteczne maszyny wykonujące określone działania, ale również jako potencjalne podmioty społeczne. W analizowanym kontekście należy przytoczyć projekty robotów społecznych (nie tylko humanoidalnych ${ }^{5}$ ), które $\mathrm{w}$ interakcjach z ludźmi wykorzystują komunikację werbalną i pozawerbalną, dodatkowo wzmacnianą próbami uczenia maszyn inteligentnego odczytywania stanów emocjonalnych człowieka. Należy dodać, że roboty społeczne wieka.

${ }^{5}$ Robot humanoidalny to sztuczny organizm (android), kształtem przypominający ciało czło- 
według Kwana M. Lee, Namkee Parka oraz Hayeona Songa są to „urządzenia, zaprojektowane w celu wywoływania społecznych interakcji za pomocą antropomorficznych kształtów (komend wydawanych przy użyciu naturalnych sposobów komunikacji, takich jak gesty oraz mowa) z użytkownikami, którzy mogą przejawiać tendencje postrzegania robotów jako aktorów społecznych" (Lee, Park i Song 2005, 539). Przykładami tego typu maszyn są między innymi robot-pomoc domowa, robot-pielęgniarz czy robot-rehablilitant Paro, coraz częściej wykorzystywane w codziennym życiu nie tylko przez osoby starsze. Roboty mogą także zastępować człowieka, służąc pomocą czy monitorując działania jego ludzkiego właściciela. Zwracają uwagę na aktywność fizyczną seniora, przyjmowanie leków, spożywanie posiłków i kontakt z innymi ludźmi. Jeśli właściciel przez pewien, ściśle określony czas nie będzie podnosił się z krzesła, robot podjedzie i zaproponuje ćwiczenia ruchowe. Alternatywnie urządzenie może zasugerować również wykonanie telefonu do kogoś znajomego. Osoba starsza może pograć z robotem, wejść w interakcję za pomocą głosu, czatbota lub ekranu dotykowego (Robot-pomoc domowa 2018) ${ }^{6}$. Robot medyczny - robot-pielęgniarz, przemieszczając się w trybie autonomicznym, sam dostarczy leki oraz próbki do badań, znacząco wspomagając personel medyczny szpitala/kliniki (Okurowski 2019) ${ }^{7}$.

Poza praktycznym aspektem wykorzystania robotów relacyjnych, zaczęto dostrzegać również tendencje antropomorfizacyjne, przejawiające się w emocjonalnym przywiązaniu i zaufaniu, często implikowanym procesem komunikacyjnym (zob. robot Eliza - zob. Weizenbaum 1966, 36-35). Zgodnie z te orią równania mediów Byrona Reevesa i Clifforda Nassa (zob. Reeves i Nass 1998) ludzie są skłonni traktować technologie tak, jakby były one realnymi, społecznie reagującymi bytami/partnerami interakcji międzyludzkich. Przykładem uspołecznienia sztucznej inteligencji (robota) poprzez jej aplikację $\mathrm{w}$ różne obszary funkcjonowania osób starszych jest m.in. rehabilitant robot Paro. Znajduje zastosowanie w medycynie w procesach rehabilitacyjnych; w edukacji jako opiekun seniorów; w rozrywce przyczyniając się do wypoczynku oraz w życiu prywatnym, niejednokrotnie odgrywając rolę przyjaciela osoby starszej.

Foka Paro, używana od 2003 roku, to zaawansowany interaktywny, terapeutyczny robot, stosowany w szpitalach i placówkach opieki społecznej. Umożliwia, a czasami poprawia socjalizację pacjentów między sobą i z opie-

\footnotetext{
${ }^{6}$ Autonomiczny robot został wyposażony w stereoskopowe kamery, interfejs dotykowy, dwukierunkowy system komunikacji audio (może mówić i rozumieć ludzką mowę) i różnorodne czujniki. Natomiast nie może wpływać na inne urządzenia znajdujące się w otoczeniu.

${ }^{7}$ Bezkolizyjną jazdę umożliwia pakiet czujników, dzięki którym robot orientuje się w przestrzeni. Punktem odniesienia w zakresie lokalizacji jest dokładna mapa placówki medycznej z zaznaczonymi obiektami stałymi (infrastruktura) oraz korytarzami w budynku.
} 
kunami, stymuluje interakcje oraz zmniejsza ich poziom stresu. Ma działanie psychologiczne i terapeutyczne, poprawiając relaksację i motywację osób starszych. Jest wyposażony w pięć rodzajów czujników/sensorów: dotykowe, światła, dźwięku, temperatury i postawy, które ułatwiają postrzeganie ludzi i ich otoczenia. Czujniki światła umożliwiają mu rozpoznanie światła i ciemność, czujnik dotykowy sprawia, że odczuwa, kiedy jest gładzony i bity lub trzymany (czujnik postawy). Paro może rozpoznać kierunek głosu i słowa, takie jak: jego imię, pozdrowienia i pochwała (czujnik dźwięku), nauczyć się zachowywać w sposób preferowany przez osobę starszą/partnera interakcji i reagować na jego nową nazwę. Zapamiętuje wcześniej usłyszane komendy i wykonywane działania. Na przykład, jeśli osoba gładzi go za każdym razem, gdy go dotyka, to robot zapamięta tę czynność i spróbuje powtórzyć tę akcję/ /działanie, aby go pogłaskać. Analogicznie reaguje w sytuacji, kiedy zostanie uderzony, zapamiętuje daną akcję/czynność i stara się jej nie wykonywać. Podczas interakcji z ludźmi robot reaguje tak, jakby był żywy, poruszając głową i nogami, wydając dźwięki i pokazując preferowane zachowanie. Imituje także głos prawdziwej foczej harfy (Paro Therapeutic 2019).

Przywołane przykłady wykazują zmianę postrzegania maszyny/robota na płaszczyźnie interakcji społecznych: z praktycznego narzędzia zaczął on stawać się potencjalnym, chociaż sztucznym towarzyszem wywołującym realne emocje. Przestał być wyłącznie artystyczną projekcją znaną osobom starszym z filmów science fiction, komiksów czy też skomplikowanym narzędziem wykorzystywanym w zakładach pracy i laboratoriach. Coraz częściej sztuczna inteligencja, technologie internetowe, maszyny cybernetyczne, roboty społeczne zastępują drugiego człowieka, ,,podejmując” także coraz więcej odpowiedzialnych decyzji (,,świat bezrefleksyjny”) (Muraszkiewicz 2019, 30).

\section{Podsumowanie}

Obecne pokolenie osób starszych tworzy pokolenie wojny, międzywojnia, Baby Boomers oraz pokolenie X. Już teraz stanowią one ponad jedną piątą ogólnej liczby ludności Polski i liczba ta wciąż wzrasta. Przyjęta teza, że świat rzeczywisty (społeczno-kulturowy) osób starszych nie nadąża za światem tworzonym i kreowanym przez nowe media i technologie została potwierdzona. Główną przyczyną, stosując terminologię Mieczysława Muraszkiewicza, obok braku chociażby jednego z czterech rodzajów dostępu, jest różnica prędkości w świecie rzeczywistym i wirtualnym, która jest konsekwencją zniesienia stałego podziału czasu, przestrzeni i odległości (Muraszkiewicz 2019, 31). Zgodnie z hipotezą Williama Ogburna (Ogburn 1975, 255-258) sfera kultury nie nadąża za rozwojem techniki, stąd zmiany w obszarze technologii wyprzedzają 
praktyki kulturowe społeczeństwa, co skutkuje między innymi tym, że osoby starsze potrzebują znacznie więcej czasu, aby nabyć kompetencje kognitywne, poznawcze, w stosunku do kompetencji operacyjnych i strategicznych.

Ubieralne technologie czy elementy Internetu Rzeczy, pomimo realizacji wielu funkcji ochronnych, zdrowotnych czy związanych z codziennym funkcjonowaniem, wciąż budzą obawy i lęk seniorów. Należy zauważyć, że osoby starsze, rezygnując z dostępu użytkowego dobrowolnie, chociaż może nie zawsze świadomie, wybierają kulturę wykluczenia. To od ich decyzji zależy, w jakim stopniu i zakresie będą wykorzystywać nowe media i technologie i czy dobrowolnie - cytując Łukasza Arendta - zdecydują się na „niebyt w cyfrowym świecie" (Arendt 2010, 22).

Inne cechy utrudniające funkcjonowanie osobom starszym w świecie nowych mediów i technologii to szybko rosnąca liczba interakcji nie tylko człowiek-człowiek, człowiek-maszyna, ale maszyna-maszyna, przewaga komunikacji (zapośredniczonej, pośredniej i ekstrapersonalnej), szczególnie widoczna u najmłodszych pokoleń, nad myśleniem analitycznym. Ludziom w podeszłym wieku trudno jest przejść od myślenia logicznego do symulacji w sztucznie wykreowanej rzeczywistości czy cyberprzestrzeni; a także zaakceptować: przewagę komunikacji wizualnej nad werbalną; zmianę podstawowych funkcji mediów (z informacyjnej w użytkową); zatarcie granicy między sferą publiczną a prywatną, między pracą, nauką i rozrywką, budowanie tożsamości nie poprzez przynależność do grup społeczno-kulturowych czy zawodowych, ale mediów społecznościowych, sieci wirtualnych, gier sieciowych czy własnych autokreacji.

Pokolenie seniorów „nie nadąża” także za próbami uspołecznienia sztucznej inteligencji. Chociaż coraz częściej innowacyjne technologie, maszyny cybernetyczne, roboty zastępują drugiego człowieka, podejmują decyzje (,świat bezrefleksyjny") (Muraszkiewicz 2019, 30), z perspektywy najmłodszych pokoleń ułatwiają życie, to wciąż wywołują one tzw. „technostres”. Tempo dokonujących się zmian determinuje świat, w którym funkcjonują i który różni się bardzo od tego, w którym przychodzili na świat, wzrastali, pracowali i odpoczywali. Jak słusznie podkreśla Piotr Sztompka, „każde pokolenie jest nosicielem takiej kultury, która została mu wpojona w dzieciństwie i młodości w procesach socjalizacji czy edukacji. Wiele kierunków psychologii, z psychoanalizą na czele, zauważa, że wczesne doświadczenia życiowe są najsilniejsze i najtrwalsze. Raz zinternalizowanych treści kulturowych trudno się oduczyć, cechują się one znacznym stopniem inercji. W społeczeństwie dzisiejszym, w którym zmiany warunków życia społecznego dokonują się w rytmie ogromnie przyspieszonym, pokolenie dzieci rodzi się już w kręgu zupełnie innej kultury niż ta, którą nosi w sobie pokolenie rodziców. Rodzice nie rozumieją muzyki rockowej, dzieci - walca wiedeńskiego" (Sztompka 2012, 
295), a pokolenie osób starszych - dziadków - innowacyjnych technologii internetowych i komunikacyjnych zmieniających podstawowe zasady funkcjonowania we współczesnym społeczeństwie, coraz bardziej robotycznym.

\section{OLDER PEOPLE IN A WORLD OF NEW MEDIA AND TECHNOLOGIES}

\section{Summary}

The aim of the article was an analysis of the situation and social-cultural conditionings of older people constituting, among others, the generation $\mathrm{X}$ in a world of new media and technologies, on a background of the youngest media generation, that is, the generation Alpha. The present generation of seniors consists of the war and inter-war generation, the Baby Boomers and generation X. After a concise characterization of generations, I presented the problem of media competences determining the phenomenon of digital divide. In turn, I discussed its three dimensions: the psychological (motivating access), the technological (material and physical access) and the sociological (competence access: strategic, informative operative skill and usable access) together with examples (wearable technologies, Internet of Things, humanoid robots) constituting the area of digital divide. The accepted thesis, in accordance with William Ogburn's concept, that the real world (social-cultural) of the elderly does not keep pace with the world created by the new media and technologies, was affirmed. The main cause, apart from a lack of even one of the four types of access, is the difference of speed in the real and virtual world. I applied the historical, analytical-descriptive and comparative methods.

Keywords: media literacy; new media and technologies; older people; digital divide

Słowa kluczowe: kompetencje medialne; nowe media i technologie; osoby starsze; wykluczenie cyfrowe

\section{BIBLIOGRAFIA}

Arendt, Łukasz. 2010. Wykluczenie cyfrowe: zagadnienia teoretyczno-empiryczne. W: Wykluczenie cyfrowe na rynku pracy, red. Łukasz Arendt, Elżbieta Kryńska. Warszawa: IPiSS.

Atzori, Luigi. Iera, Antonio. Morabito, Giacomo. 2010. The Internet of Things: A survey, Computer Networks, 54, 280.

Baby Boomers. W: Encyclopedia Britannica, 23.02.2013. 2019. Dostęp: 9.02.2019. http://www.britannica.com/EBchecked/topic/47555/baby-boom.

Bochyńska, Nikola. 2019. Technologie ubieralne - inteligencja przyszłości?, 4.07.2016. Dostęp: 7.02.2019. https://www.gb.pl/technologie-ubieralne-inteligencja-przyszlosci-pnews-843.html. 
Coupland, Douglas. 2008. Pokolenie X. Opowieści na czasy przyśpieszającej kultury. Tłumaczenie Jan Rybicki. Warszawa: G+J Gruner+Jahr Polska.

Główny Urząd Statystyczny. 2020. Rocznik Demograficzny 2020, red. Dominik Rozkrut. Warszawa: Zakład Wydawnictw Statystycznych.

Główny Urząd Statystyczny. 2019. Rocznik Statystyczny Rzeczypospolitej Polskiej 2018, red. Dominik Rozkrut. Warszawa 28.12.2018, s. 209. Dostęp: 6.02.2019. http://stat.gov.pl/obszary-tematyczne/roczniki-statystyczne/roczniki-statystyczne/rocznik-statystyczny-rzeczypospolitej-polskiej-2018,2,18.html.

Gruchoła, Małgorzata. 2014. Od pokolenia X do pokolenia Alpha - wartości mediów. W: Współczesne media. Wartości w mediach - wartości mediów, t. 2: Wartości mediów, red. Iwona Hofman, Danuta Kępa-Figura. 31-48. Lublin: Wydawnictwo Uniwersytetu Marii Curie-Skłodowskiej.

Gruchoła, Małgorzata. 2015. Internet Web $3.0 \mathrm{w}$ społeczeństwie transgresyjnym - Internet wykluczania?. Spoleczeństwo i Rodzina, 42, 1, 113-128.

Gruchoła, Małgorzata. 2016. Pokolenie Alpha - nowy wymiar tożsamości?. Rozprawy Społeczne, $10,3,5-13$.

Gruchoła, Małgorzata. 2017. Nowe formy zachowań społecznych wobec i pod wpływem mediów oraz nowych technologii: analizy porównawcze. Państwo i Spoleczeństwo, 17, 3, 123-133.

Grzesiak, Mateusz. 2019. 21 różnic pokoleniowych między Baby boomers, X i Y, 1.11.2014. 2019. Dostęp: 9.02.2019. https://mateuszgrzesiak.natemat.pl/122459,21-roznic-pokoleniowychmiedzy-baby-boomers-x-i-y.

Internet of Things - Strategic Research Roadmap: IERC, 15.09.2009. 2019. Dostęp: 20.01.2019. http://www.grifs-project.eu/data/File/CERP-IoT\%20SRA_IoT_v11.pdf.

Isaksen, Judy. 2019. Generation X, in: International encyclopedia of the social sciences, 12.09.2009. Dostęp: 14.02.2019. http://www.encyclopedia.com/topic/Generation_X.aspx\#1.

Janiszewska, Barbara. 2019. Cyfrowe kompetencje Polaków, 24.06.2017. Dostęp: 5.02.2019. http:// www.sprawynauki.edu.pl/3650-cyfrowe-kompetencje-polakow.

Kantar Public. 2017. Umiejętności cyfrowe Polaków i Europejczyków, oprac. U. Krassowska. Warszawa: Eurobarometer 87.1, K.039/17.

Kokot, Wincenty. Kolenda, Paweł. Czym jest Internet Rzeczy. W: Internet Rzeczy w Polsce, red. Paweł Kolenda. 8-11. Warszawa: IAB Polska. 2015.

Kwiatkowska, Ewa M. 2014. Rozwój Internetu rzeczy - szanse i zagrożenia. Internetowy Kwartalnik Antymonopolowy i Regulacyjny, 8(3), 60-70.

Lee, Kwan Min. Park, Namkee. Song, Hayeon. 2005. Can a robot be perceived as a developing creature: effect of a robot's long-term cognitive developments on its social presence and people's social responses toward it. Human Communication Research, 31, 538-563.

McCrindle, Mark. Wolfinger, Emily. 2009. The ABC of XYZ: Understanding the Global Generations, London.

Mejssner, Barbara. 2019. Internet Rzeczy. Nawet prysznic może zostać szpiegiem, 4.06.2018. Dostęp: 8.02.2019. https://pieniadze.rp.pl/lifestyle/madre-wydatki/15359-internet-rzeczy-nawetprysznic-moze-zostac-szpiegiem.

Muraszkiewicz, Mieczysław. 2019. Otwarte społeczeństwo sieciowe. Krok w stronę uniwersalizmu sieciowego, 8.06. 2010. Dostęp: 15.02.2019. https://www.slideserve.com/xandy/m-muraszkiewicz.

Ogburn, William. 1975. Hipoteza opóźnienia kulturowego. W: Elementy teorii socjologicznych. Materiały do dziejów współczesnej socjologii zachodniej, red. Włodzimierz Derczyński, Aleksandra Jasińska-Kania, Jerzy Szacki. 255-258. Warszawa: Państwowe Wydawnictwo Naukowe.

Okurowski, Tomasz. 2019. Robot w szpitalu. Prawie jak pielęgniarka, 21.10.2015. Dostęp: 7.02.2019. https://nt.interia.pl/raporty/raport-medycyna-przyszlosci/medycyna/news-robot-wszpitalu-prawie-jak-pielegniarka,nId,1906310.

Paro Therapeutic Robot, 7.12.2003. 2019. Dostęp: 6.02.2019. http://www.parorobots.com/.

Reeves, Byron. Clifford Nass. 1998. The Media Equation: How People Treat Computers, Television, and New Media Like Real People and Places, Stanford: Stanford University. 
Robot-pomoc domowa dla starszych, 20.08.2013. Dostęp: 7.02.2018. http://maxmania.pl/technologie/robot-pomoc-domowa-dla-starszych/.

Sadowski, Robert. 2019. Raport Newspoint: Pokolenia $w$ Polsce i potrzeba monitorowania ich rosnacej aktywności, 21.03.2018. Dostęp: 11.02.2019. https://blog.newspoint.pl/index. php/2018/03/21/raport-newspoint-pokolenia-w-polsce-i-potrzeba-monitorowania-ich-rosnacejaktywnosci/.

Sitnik, Michał. 2019. Blog: Lively - ubieralne technologie i czujniki dla seniora, 6.12.2014. Dostęp: 8.02.2019. https://tabliczni.pl/ios/blog-lively-ubieralne-technologie-i-czujniki-dla-seniora/.

Szarota, Zofia. 2013. Społeczno-demograficzne aspekty starzenia się społeczeństwa. W: Remigiusz J. Kijak, Zofia Szarota, Starość. Między diagnoza a działaniem. 6-22. Warszawa: Centrum Rozwoju Zasobów Ludzkich.

Szewczyk, Agnieszka. 2006. Oblicza ubóstwa w spoleczeństwie informacyjnym. Warszawa: Wydawnictwo Naukowe PWN.

Sztompka, Piotr. 2012. Socjologia. Analiza społeczeństwa. Kraków: Wydawnictwo Znak.

Tomaszewski, Rafał. 2019. Ubrani w pomoc. Telemedycyna dla mieszkańców Wielkopolski, 5.09.2017. Dostęp: 8.02.2019. https://fintek.pl/ubrani-pomoc-telemedycyna-mieszkancowwielkopolski/.

Top definition: Generation Alpha, 30.04.2016. 2019. Dostęp: 06.02.2019. http://pl.urbandictionary. com/define.php?term=Generation+Alpha.

Turkle, Sherry. 2013. Samotni razem. Dlaczego oczekujemy więcej od zdobyczy techniki, a mniej od siebie nawzajem. Tłumaczenie Małgorzata Cierpisz. Kraków: Wydawnictwo Uniwersytetu Jagiellońskiego.

Weizenbaum, Joseph. 1966. ELIZA-A Computer Program For the Study of Natural Language Communication Between Man and Machine. Commungicatins of the ACM, 9, 1, 36-35.

Van Dijk Jan. 2010. Społeczne aspekty mediów. Analiza społeczeństwa sieci. Tłumaczenie Jacek Konieczny. Warszawa: Wydawnictwo Naukowe PWN.

Zalecenie Rady z dnia 22 maja 2017 r. w sprawie europejskich ram kwalifikacji dla uczenia się przez całe życie i uchylające zalecenie Parlamentu Europejskiego i Rady z dnia 23 kwietnia 2008 r. W sprawie ustanowienia europejskich ram kwalifikacji dla uczenia się przez całe życie (2017/C 189/03). 2019. Dostęp: 18.02.2019. https://ec.europa.eu/ploteus/sites/eac-eqf/files/pl.pdf.

Matgorzata Gruchola - prof. KUL dr hab., kierownik Katedry Komunikacji Wizualnej i Nowych Mediów w Instytucie Dziennikarstwa i Zarządzania KUL, socjolog i kulturoznawca. Podejmowane problemy badawcze koncentrują się wokół następujących zagadnień: komunikacja wizualna w nowych mediach i technologiach informacyjno-komunikacyjnych, etapy rozwoju internetu (Web. $1.0-$ Web. 5.0, Internet semantyczny, Internet Rzeczy) w aspekcie kultury wizualnej, społeczno-kulturowe determinanty społeczeństwa informacyjnego, sieciowego oraz wiedzy, kultura medialna i robotyczna, kompetencje medialne, formy ochrony odbiorców/użytkowników mediów i nowych technologii (instytucjonalne, prawne, konsumenckie, edukacyjne). Członek: Polskiego Towarzystwa Badań nad Filmem i Mediami; Polskiego Towarzystwa Edukacji Medialnej; Polskiego Towarzystwa Komunikacji Społecznej; Polskiego Towarzystwa Kulturoznawczego; członek korespondent Towarzystwa Naukowego KUL.

Kontakt: malgorzata.gruchola@kul.pl 